\title{
The Productivity of Italian Industrial Suppliers (1998-2006). Does Participation in Global Value Chains Matter?
}

Mariarosaria Agostino, Anna Giunta, Jeffrey B. Nugent, Domenico Scalera and Francesco Trivieri

\section{(2) OpenEdition}

Journals

Electronic version

URL: https://journals.openedition.org/rei/5691

DOI: 10.4000/rei.5691

ISSN: 1773-0198

Publisher

De Boeck Supérieur

\section{Printed version}

Date of publication: 1 December 2013

Number of pages: 85-112

ISBN: 9782804185701

ISSN: 0154-3229

Electronic reference

Mariarosaria Agostino, Anna Giunta, Jeffrey B. Nugent, Domenico Scalera and Francesco Trivieri, "The Productivity of Italian Industrial Suppliers (1998-2006). Does Participation in Global Value Chains Matter?", Revue d'économie industrielle [Online], 144 | 4e trimestre 2013, Online since 01 December 2015, connection on 07 June 2022. URL: http://journals.openedition.org/rei/5691 ; DOI: https:// doi.org/10.4000/rei.5691 


\title{
THE PRODUCTIVITY OF ITALIAN INDUSTRIAL SUPPLIERS (1998-2006). DOES PARTICIPATION IN GLOBAL VALUE CHAINS MATTER?*
}

\author{
Mariarosaria Agostino, Università della Calabria, Italy \\ Anna Giunta, Università Roma Tre, Italy \\ Jeffrey B. Nugent, University of Southern California, USA \\ Domenico Scalera, Università del Sannio, Italy \\ Francesco Trivieri, Università della Calabria, Italy
}

Mots clés: Chaînes de valeur globales, productivité, fournisseurs.

\section{Keywords: Global Value Chains; Productivity; Supplier Firms.}

\section{INTRODUCTION}

Over the last twenty years the fragmentation of production processes in manufacturing industry, which had already started in previous decades, gathered new momentum, strongly characterised by the international reach of decentralisation, as documented by a great deal of evidence (e.g. van Welsum, 2004; Havik and Mcmorrow, 2006; OECD, 2007; Cattaneo et al., 2013). Thanks to the increasing possibility to separate production stages in time and space, the production process of almost every good (from computers to retail trade services) has been progressively disaggregated into a coordinated series of distinct "tasks" (Grossman and Rossi-Hansberg, 2006; Miroudot and Ragoussis, 2009), located outside the final assembling firm, either in the home country or abroad, thus originating a new model of the international

We wish to thank for their useful comments the participants in the Workshop on "Manufacturing Renaissance? Structural changes and consequences for industrial economics" held in Ferrara (Italy) on 17-18 May 2013. 
division of labour, initiating a growing variety of relationships among firms, and spurring the development of global value (or supply) chain ${ }^{\mathrm{I}}$.

Global value chains (henceforth, GVCs) "encompass the full range of activities" carried out in different firms, often located in different countries, "that are required to bring a good or service from conception through the different phases of production [...] to delivery to final consumers" (Cattaneo et al., 20Io, pp. 3-4). As they have become a widespread organization mode of production both in developing and advanced countries, a large number of economists and social scientists have been dealing with many different implications of GVCs upsurge. First of all, the impact of GVCs development on international trade flows has been so massive to push authoritative economists to point out the need of "a new paradigm for studying international trade that emphasizes not only the exchange of complete goods, but also trade in specific tasks" (Grossman and RossiHansberg, 2006, p. 60; Baldwin and Robert-Nicoud, 20Io). Secondly, the effects of GVCs rise on developing and emerging countries, and specifically on firms' technological skills (Morrison et al., 2008; Winkler, 2013) and capability to move up in the international hierarchy of value-added activities (Humphrey and Schmitz, 2002), productivity, export, economic growth (Havik and Mcmorrow, 2006; Gereffi and Frederick, 20Io) and workers' social upgrading (Barrientos et al., 2oIr; Planck and Staritz, 2013) have been extensively investigated. A wide strand of the literature has also focused on large firms' motivations to externalise stages of production through outsourcing and/or offshoring, and take part in GVCs as large buyers (Antras, 2003 and 2005; Antras and Helpman, 2004 and 2008; Melitz, 2003; Helpman et al., 2004; Greenaway and Kneller, 2007). Others (Dries and Swinnen, 2004; Hanson et al., 2005) have in particular emphasized the role played by multinational firms locating input processing in their foreign affiliates, thereby creating global vertical production networks.

I Different terminology has been used by authors in dealing with the phenomenon we describe. Examples include: new international division of labour (Fröbel et al., i98r; Marin, 2006); disintegration of production (Feenstra, 1998); fragmentation (Arndt and Kierzkowski, 200I); vertical specialization (Hummels et al., 200I) and international technological diffusion (Frantzen, 2000). The evolving model of division of labour among firms and countries has called into question the appropriateness of the traditional concept of comparative advantage, possibly to be replaced by the concept of "vertical comparative advantage" (Beaudreau, 20II). 
Conversely, specific research on suppliers, which represent the bulk of firms participating in GVCs is scant (exceptions being, for example, Kimura, 2002; Innocenti and Labory, 2004; Agostino et al., 201I; Giunta et al., 2012). Suppliers are those firms (especially small and medium sized firms) selling intermediate inputs to other producers. In many (both developed and developing) countries, they account for a high percentage of total firms (Barba Navaretti et al., 20II) and constitute the backbone of GVCs. However, although a rather natural conjecture is that functioning of GVCs and suppliers' performance and survival are closely intertwined, the issue has been almost neglected by the literature.

A relevant exception is represented by the Global Value Chain Approach (henceforth GVCA), a strand of literature initiated by Gereffi (1994), and subsequently enhanced by Gereffi (1999), Kaplinski (2000), Henderson et al. (2002) and Humphrey and Schmitz (2002), which has proposed a theoretical framework focused on the governance of chains, the coordination of participants' activities, the features of relationships among firms inside the network. In this view, GVCs are meant not merely as the sum of bilateral connections among firms but rather as a complex set of relationships coordinated by key agents and based on some mixed form of hierarchy and/or cooperation among participants. In particular, the governance of GVCs is believed to be essential in defining incentives, constraints and therefore the behaviour and performance of participants in the chain.

This latter remark is the GVCA insight more relevant to this paper. The working hypothesis of our analysis is that crucial factors to explain suppliers' productivity are the insertion of suppliers in global (rather than local) value chains and the type of governance of the GVC which supplier firms are inserted into. In GVCs with advanced governance relations (the ones defined "relational" GVCs in section 2), suppliers are able and probably even required to become directly involved in strategic stages of production and therefore to be endowed with adequate technical and relational capabilities. In "captive" GVCs, the ones with the least advanced type of governance, several suppliers source the same intermediate good and the competition among them is fierce, based merely on price. In this framework, heterogeneity of suppliers (i.e. different productivity performances) naturally correspond to different endowments of capabilities and in turn to diverse models of chains' governance, where suppliers in 
relational GVCs are expected to be more skilful and show higher productivity than others.

Testing this hypothesis, or otherwise giving an answer to the question "Does participation in global value chains matter?" is the main purpose of this paper. To do that, we carry out an econometric investigation by employing data on a representative sample of 3,904 Italian manufacturing firms, drawn from a unique database spanning the period 1998-2006. In the absence of direct information on the kind of governance of GVCs to which the suppliers of our sample belong, we identify the suppliers joining advanced-governance GVCs as the ones with higher propensity to export and innovate. These peculiar skills look particularly important because on one side joining a global (rather than local) value chain requires organizational capabilities sufficient to establish and maintain long term relationships with foreign buyers, while on the other the complexity of relationships involved by the participation in relational GVCs implies adequate technical skills and innovativeness.

Then, after splitting our sample in two subsamples, including respectively a) exporting and innovating and b) non-exporting and non-innovating firms, we test whether statistically significant differences in Total Factor Productivity (TFP) and labour productivity (LAPR) arise between suppliers and final firms in each subsample. Consistent with suggestions of GVCA, we expect to find evidence showing that the productivity of suppliers is closer to that of final firms in the subsample of innovating and exporting firms (to which suppliers of relational GVCs belong) than in the other subset.

The results we obtain are pretty clear and robust. When comparing productivity in the subsample of non-innovating and non-exporting, suppliers (supposed to be the ones prevalently belonging to captive chains) show a statistically significant gap with respect to (non-innovating nonexporting) final firms. Conversely, in the comparison made for the subsample of exporting and innovating firms, no significant differences emerge between suppliers (very likely, the ones belonging to relational chains) and final firms. Our conclusion is therefore that as a consequence of their participation in GVCs with advanced type of governance, these latter suppliers benefit from the incentives and seize the opportunities to 
raise their productivity to the extent that the gap between suppliers and final firms can be eliminated. Notably, the gap is filled not by the acquisition of abilities in itself (comparisons are made between groups of firms with the same level of ability) but rather by participation in relational GVCs.

The paper is organised as follows. After this introduction, Section 2 recalls the recent evolution of Italian industrial suppliers and reviews the most relevant insights and contributions of GVCA, to highlight why joining, maintaining participation, and moving up global value chains may be seen as vital intermediate targets for suppliers in the face of the threats and opportunities brought about by globalization. Section 3 is devoted to the empirical investigation: section 3.I presents data and some basic descriptive statistics; section 3.2 illustrates aims, strategy and methods of estimation, considering both Total Factor Productivity (TFP, section 3.2.I and 3.2.2) and LAbour PRoductivity (LAPR, section 3.2.3); section 3.3 shows the results of the empirical investigation by comparing suppliers and final firms' productivity. Finally, section 4 collects the main conclusions and summarizes the central result of the paper: participating in GVCs matters to the extent that chains give incentives to suppliers in terms of capabilities' enhancement and skills' upgrading.

\section{ITALIAN INDUSTRIAL SUPPLIERS IN GLOBAL VALUE CHAINS}

The Italian industrial structure has been traditionally characterised by a fairly small average firm size and a widespread presence of suppliers. The international fragmentation of production of the last decades has triggered a series of relevant consequences, especially for small and medium sized suppliers. In the industrial districts of Central and North-Eastern Italy the globalisation of the intermediate factor markets has caused a heavy blow for this model of productive organisation. In fact, resort to the offshoring has been driving the larger firms to quest outside the districts in search of low supply costs in Central-Eastern Europe, the Balkans, the Mediterranean basin and Southeast Asia. Even for the South of Italy (the less developed area of the country), dispersion of production beyond the country's borders has brought in its share of worrying consequences, as 
Southern suppliers, usually less efficient, productive and inclined to grow have proven to be also the least equipped to stand up to the pressure of low-cost international competition (Giunta and Scalera, 2007; Giunta et al., 2012).

Trying to cope with the shock of globalisation, Italian industrial suppliers have changed their behaviour and features. The traditional supplier typology, prevalent in the period of production decentralisation brought on by the crisis of the Fordist firm in the I970s, has in the last decade practically disappeared ${ }^{2}$. In order to survive the globalisation of the intermediate factor markets or even find in it an opportunity for consolidation and growth, suppliers have been called to set out along a virtuous path of evolution in terms of market, functions and characteristics. As described in detail by the managerial literature (for example Camuffo et al., 2007), suppliers have tried in the first place to extend their own market, serving a relatively high number of clients, not only local nor only national. With its clients they have developed relations on a steady footing, no longer characterised by relations of technological and economic subordination, merely carrying out the clients' orders, but rather by collaboration and complementarity, taking the form of participation in the decisions relevant to production and proposing models and solutions to address the clients' problems. Often, a supplier firm of this type has in turn become itself client to a group of other suppliers, normally operating on a smaller scale and with less advanced characteristics ${ }^{3}$.

All this has significant repercussions in terms of the functions performed. The need to extend the range of clients (in particular abroad) implies arriving at levels of productivity sufficient to cover the fixed costs of access to foreign markets, while the need to serve buyers whose demand is

2 We refer to the character of captive supplier, greatly dependent on a single monopsonist or very few clients, physically close to the final market and admitted to a part in the value chain thanks to the capacity to reduce costs rather than specialization and technical knowledge. This kind of supplier has been studied for many countries, including France (Sallez, 1977), Japan (Aoki, 1988; Kimura, 2002) and Italy (Innocenti and Labory, 2004). For reconstruction of the role played by traditional suppliers, see Taymaz and Kilicaslan (2005).

3 Taking the example of the Italian fashion system (textiles, clothing and leather), "a proportion of suppliers ranging from year to year between $45 \%$ and $55 \%$... in turn makes use of external manufacturers" (Comitato Network Subfornitura, 2008). 
differentiated and increasingly complex in technological terms calls for a significant step forward in project and design skills. Moreover, active pursuit of market outlets implies the appropriate development of functions in terms of product promotion and positioning, research and defence of profitable market niches. Finally, it has become important for suppliers to be able not only to participate in the production network but also to contribute to its governance. The example of the "platform firms" in the textile industry is illuminating in this connection ${ }^{4}$.

However, according to an increasing number of studies, only a part of Italian industrial suppliers have been able to follow the described virtuous path ${ }^{5}$. One of the main motivations of this paper is to understand which suppliers have been successful in adapting to the new competitive context and why. Our conjecture are that suppliers' individual capabilities matter, but that also the nature of relations with their partners in

4 As is well illustrated in Comitato Network Subfornitura (2008), "In clothing and the leather/skin value chains four stylised categories of suppliers emerge showing increasing organisational complexity: stylist outside contractors, advanced outside contractors, coordinators and platform firms. The stylist works on a single stage, usually sewing, with limited investment in a highly competitive market. The advanced outside contractor completes sewing with industrial services such as cutting, finishing and ironing, quality control and raw material logistics; it may be the leading stylist workshop making use of other outside contractors for the services. The coordinator may carry out the cutting and finishing stages directly, but more often coordinates these activities, managing stylists, suppliers of industrial services and high value-added services. It also deals with the raw material logistics. It must have a good knowledge of materials, the manufacture stages and the intermediate markets. In addition, it also performs marketing activities. Its financial management is more complex, as is the firm organisation. The platform firm has an internal structure for the production of immaterial services: modelling, style and design. It works equally in the fields of production and marketing. The platform firm shows considerable organisational and coordination skills since large firms with their own commercial trademarks delegate to them manufacturing activities and the management of a high number of subcontractors [...]. Once the buying office of a large firm would have had no choice but to coordinate many subcontracting firms directly to obtain the finished articles for a season's order. Nowadays the activities of the buying offices have been simplified and relieved of many tasks thanks to the work of the platform firms specialised in supply chain management".

5 Evidence in this direction is offered for example by Amighini and Rabellotti (2003), MET (2009), Razzolini and Vannoni (20II), Accetturo et al. (20II), Toschi (20I2), Accetturo et al. (2012) and Giunta et al. (2012). 
GVCs are important. More precisely, we believe that the GVCs development has triggered powerful incentives for Italian (as well as other developed countries') suppliers to upgrade their skills in order to fulfil the requirements of global buyers. This has happened in particular in chains (or segments of chains) characterised by more complex relationships among the participants and a more advanced model of governance.

This interpretation is consistent with the theoretical framework proposed by the GVCA. In this view, relations among participants to GVCs are shaped by the type of chain governance adopted by lead firms. Three distinct types of governance (i.e., relational, modular and captive) ${ }^{6}$ have been singled out by Gereffi et al. (2005) and many others (e.g. Gereffi, 1999; Bair and Gereffi, 200I; Dolan and Humphrey, 2000; Galvin and Morkel, 200I; Sturgeon, 2002; Humphrey, 2003; Sturgeon and Florida, 2004; Pietrobelli and Rabellotti, 2007). Relational value chains are characterized by close relationships between suppliers and lead firms wherein the former become directly involved in strategic stages of production, such as design and product development. In modular value chains, lead firms provide design specifications to supplier firms that manufacture components, modules and/ or subsystems (Sturgeon and Lester, 2004; Gereffi et al., 2005). Finally, in captive value chains, several suppliers can source the same intermediate good and the competition among them is fierce, mainly based on price.

According to GVCA, participation in GVCs can affect the behaviour and the performance of suppliers in several ways, providing them with a potentially valuable opportunity to obtain managerial expertise, technical knowledge, innovation channels, and new markets, thereby enhancing their productivity, efficiency and growth. GVCA scholars (Dolan and Humphrey, 2000; Bair and Gereffi, 200r; Bazan and Navas-Aleman, 2004; Giuliani et al., 2005) identify four distinct channels for suppliers' upgrading and improved performance: (a) product innovation (increasing the ability of supplier firms to supply higher value added, more sophisticated products); (b) process innovation (increasing the technical efficiency of the production process); (c) functional upgrading (improving the quality of supplier's operations along the GVCs, or moving to higher quality functions, e.g., from production to design); and (d) inter-chain upgrading

6 In their study of the value chain led by IKEA, Ivarsson and Alstam (20Io) add one more type, the "developmental" governance structure. 
(applying the competence acquired in a particular function so as to move into a new chain) 7 .

Value chain governance, incentives to GVCs participants and suppliers' capabilities are closely connected to each other. The type of value chain governance is related to the complexity of inter-firm transactions and the capabilities of suppliers to codify specifications for complex transactions and to assure that all the requirements needed for such transactions are satisfied (Gereffi et al., 2005). As a consequence, suppliers with low capabilities usually participate in captive GVCs, gain only thin margins and are exposed to the risks of being crowded out. Conversely, suppliers with high capabilities take part in relational GVCs where transactions are complex and cannot be fully specified. Finally, those with intermediate capabilities usually operate in modular GVCs, characterized by codified specifications of standardized modular goods. It follows that the technical and relational abilities of the individual firm can be important determinants of supplier performance by themselves and also because they allow suppliers to join the most advanced chains or segment of chains and benefit from the incentives and rewards in terms of efficiency and productivity. In particular, the propensity to penetrate foreign markets, on the one hand, and the ability to introduce process and product innovations, on the other, are consistently viewed as the most important determinants of a firm's ability to exploit the opportunities offered by participation in GVCs.

\section{AN EMPIRICAL INVESTIGATION ON SUPPLIERS' PRODUCTIVITY}

The aim of this investigation is to evaluate on the empirical ground whether and how much suppliers' capabilities and participation in GVCs matter in determining their productivity performance. To this end, we will begin by carrying out some descriptive statistical analysis, to highlight the

7 Ponte and Ewert (20II, p. I647) argue that long-established terms in such literature such as 'process, product, functional and inter-sectorial upgrading' "should be used only as partial guides to arrive at a more complex and fine-tuned picture of supplier firms' upgrading". For example, in the case of South African wine producers, it may be appropriate to apply upgrading to firms involved in GVCs, even if they thereby manage to "reach a better deal", or a better balance between risks and rewards. 
characteristics of the firms under investigation and point out possible differences in the propensity to export and innovate among different groups of suppliers and between suppliers and other firms. Subsequently, the econometric estimation will be devoted to assess the role of firms' capabilities in determining firms' performance (in terms of both TFP and labour productivity), distinguishing between the group of suppliers and final firms in order to evaluate possible peculiarities. To estimate the effect of participation in GVCs, firms will be split in subsets of different capabilities to test whether taking part in advanced type GVCs (the ones entered by the most capable suppliers) permits them to fill the productivity gap with final firms.

\subsection{Data and descriptive statistics}

Table I displays some relevant features of our sample of 3,904 industrial firms drawn from the $8^{\text {th }}$ (1998-2000), $9^{\text {th }}(200 \mathrm{I}-2003)$ and ${ }^{\text {th }}{ }^{\text {th }}(2004-2006)$ waves of the Unicredit three-year "Survey on manufacturing firms" ${ }^{8}$. In Table I, as well as in the rest of the paper, we use the information provided by each firm on its sales-to-order over total-sales ratio as an indicator of the supplier firm status. This because selling to order is the most common channel of sales among suppliers of intermediate goods (Unicredit, 2008), as most of these inputs are customized for specific productive processes and client firms. In particular we consider suppliers the firms selling only to order since: a) this choice permits us to avoid the puzzling problem of determining a threshold of the sales-to-order over total-sales ratio to distinguish suppliers from other firms, and b) the number of firms selling to both accounts for only about $20 \%$ of the overall sample.

8 Since 1982 the Italian financial Unicredit Group (formerly Capitalia and Mediocredito Centrale) has conducted three-year surveys on Italian industrial firms with at least II employees, concerning a large number of variables relative to firm size, finance, investments, innovation, internationalization and other issues. The sample contains about I2\% (in terms of both turnover and employment) of the total population of firms with II or more employees. The stratification variables are size, industry and geographical location. The shares of each stratum are determined by the Neyman allocation method. Each surveyed firm is asked to provide a ro-year time series for a selected number of balance sheet variables and, more importantly, the values of a large number of organizational, structural and performance variables for the current year and, in some cases, for the previous year or two. For further information on the Unicredit Survey sample and sampling method, see Unicredit (2008). 
Table 1. (Panel A) - Firms distribution for level of abilities, industry and size

\begin{tabular}{|c|c|c|c|c|c|c|c|c|c|c|}
\hline & \multicolumn{2}{|c|}{$\begin{array}{l}\text { ABILITIES = } \\
\text { 1998-06 2004-06 }\end{array}$} & \multicolumn{2}{|c|}{ ABILITIES = I } & \multicolumn{2}{|c|}{ ABILITIES $=2$} & \multicolumn{2}{|c|}{ ABILITIES $=3$} & $\begin{array}{r}\text { T0 } \\
\text { I998-06 }\end{array}$ & $\begin{array}{l}\text { TAL } \\
2004-06\end{array}$ \\
\hline Traditional & $30.48 \%$ & $29.22 \%$ & $29 \cdot 33 \%$ & $27.69 \%$ & $26.99 \%$ & $28.65 \%$ & $\mathrm{I} 3.20 \%$ & $\mathrm{I} 4.44 \%$ & Iо०\% & Іо०\% \\
\hline Scale intensive & 31.68\% & $30.84 \%$ & $29.12 \%$ & $27.74 \%$ & $26.95 \%$ & $28.24 \%$ & $\mathrm{I} 2.25 \%$ & 13.18\% & $100 \%$ & I0०\% \\
\hline Specialized & $20.89 \%$ & $19.90 \%$ & $29 \cdot 35 \%$ & $29.98 \%$ & $27.47 \%$ & $26.11 \%$ & $22.29 \%$ & $24.01 \%$ & Іо०\% & 100\% \\
\hline Science based & $20.52 \%$ & $17.06 \%$ & $32.79 \%$ & $33.69 \%$ & $26.01 \%$ & $26.35 \%$ & $20.68 \%$ & $22.89 \%$ & Іо०\% & Іо०\% \\
\hline Total & $27.61 \%$ & $26.47 \%$ & $29.44 \%$ & $28.58 \%$ & $27.07 \%$ & $27.78 \%$ & $15.87 \%$ & $17.17 \%$ & $100 \%$ & $100 \%$ \\
\hline II -49 & $33.83 \%$ & $3 \mathrm{I} .57 \%$ & $30.33 \%$ & $29.93 \%$ & $25.46 \%$ & $26.96 \%$ & I0.37\% & II. $53 \%$ & Іо०\% & Іо०\% \\
\hline $50-\mathrm{I} 49$ & I9. $62 \%$ & $17.59 \%$ & $29.96 \%$ & $28.21 \%$ & $29.59 \%$ & $29.94 \%$ & $20.84 \%$ & $24.25 \%$ & І0о\% & 100\% \\
\hline $150-250$ & $\mathrm{I} 4.62 \%$ & I $4.53 \%$ & $28.55 \%$ & $24.08 \%$ & $30.19 \%$ & $28.63 \%$ & $26.64 \%$ & $32.75 \%$ & І0०\% & Іо०\% \\
\hline$>250$ & I5.00\% & I4.94\% & $22.20 \%$ & $20.74 \%$ & $29.23 \%$ & $28.09 \%$ & $33 \cdot 57 \%$ & $36.23 \%$ & Іо०\% & І0०\% \\
\hline Tota1 & $27.61 \%$ & $26.47 \%$ & $29.44 \%$ & $28.58 \%$ & $27.07 \%$ & $27.78 \%$ & $15.87 \%$ & $17.17 \%$ & $100 \%$ & $100 \%$ \\
\hline
\end{tabular}

\section{Table 1. (Panel B) - Suppliers to total number of firms for level of abilities, industry and size}

\begin{tabular}{|c|c|c|c|c|c|c|c|c|c|c|}
\hline & \multicolumn{2}{|c|}{$\begin{array}{c}\text { ABILITIES }=0 \\
\text { I998-06 2004-06 }\end{array}$} & \multicolumn{2}{|c|}{$\begin{array}{c}\text { ABILITIES = I } \\
\text { 1998-06 2004-06 }\end{array}$} & \multicolumn{2}{|c|}{$\begin{array}{c}\text { ABILITIES = } 2 \\
\text { I998-06 2004-06 }\end{array}$} & \multicolumn{2}{|c|}{$\begin{array}{c}\text { ABILITIES }=\mathbf{3} \\
\text { I998-06 2004-06 }\end{array}$} & $\begin{array}{r}\text { T0' } \\
\text { 1998-06 }\end{array}$ & $\begin{array}{l}\text { TAL } \\
\text { 2004-06 }\end{array}$ \\
\hline Traditional & $69 \cdot 37 \%$ & $73.15 \%$ & $67.69 \%$ & $70.36 \%$ & $65.72 \%$ & $67.87 \%$ & $62.38 \%$ & $64.15 \%$ & $66.71 \%$ & $69 \cdot 57 \%$ \\
\hline Scale intensive & $68.62 \%$ & $69.38 \%$ & $70.31 \%$ & 71.38\% & 6г.69\% & $63.33 \%$ & $65 \cdot 71 \%$ & $66.44 \%$ & $66.50 \%$ & $67.84 \%$ \\
\hline Specialized & $78.36 \%$ & $80.19 \%$ & $73.97 \%$ & $74.89 \%$ & $70.25 \%$ & $70.92 \%$ & $69.85 \%$ & $70.93 \%$ & $72.24 \%$ & $73.96 \%$ \\
\hline Science based & $70.87 \%$ & $72.15 \%$ & $70.94 \%$ & 7I.15\% & $68.94 \%$ & 71.31\% & $65.63 \%$ & $63.21 \%$ & $69.14 \%$ & $69.55 \%$ \\
\hline Total & $71.15 \%$ & $73.72 \%$ & $70.09 \%$ & $71.90 \%$ & $66.36 \%$ & $67.89 \%$ & $65.99 \%$ & $67.05 \%$ & $68.72 \%$ & $70.44 \%$ \\
\hline $\mathrm{II}-49$ & $33.83 \%$ & $31.57 \%$ & $30.33 \%$ & $29.93 \%$ & $25.46 \%$ & $26.96 \%$ & 10. $37 \%$ & II. $53 \%$ & IO०\% & $100 \%$ \\
\hline $50-149$ & I9. $62 \%$ & $\mathrm{I} 7 \cdot 59 \%$ & $29.96 \%$ & $28.21 \%$ & $29 \cdot 59 \%$ & $29.94 \%$ & $20.84 \%$ & $24.25 \%$ & IO०\% & $100 \%$ \\
\hline $150-250$ & $14.62 \%$ & $\mathrm{I} 4.53 \%$ & $28.55 \%$ & $24.08 \%$ & $30.19 \%$ & $28.63 \%$ & $26.64 \%$ & $32.75 \%$ & IOO\% & I0०\% \\
\hline$>250$ & $\mathrm{I} 5.00 \%$ & I $4.94 \%$ & $22.20 \%$ & $20.74 \%$ & $29.23 \%$ & $28.09 \%$ & $33 \cdot 57 \%$ & $36.23 \%$ & IOO\% & I00\% \\
\hline Total & $71.15 \%$ & $73.72 \%$ & $70.09 \%$ & $71.90 \%$ & $66.36 \%$ & $67.89 \%$ & $65.99 \%$ & $67.05 \%$ & $68.72 \%$ & $70.44 \%$ \\
\hline
\end{tabular}

ABILITIES $=3$ means that the firm is an exporter (i.e. the share of its exports in total sales exceeds $15 \%$, which is the sample median) and has achieved both product and process innovations. ABILITIES $=2$ means that the firm is either an exporter that has carried out only one kind of innovation or a non-exporter that has carried out both kinds of innovation. ABILITIES $=\mathrm{I}$ if the firm is an exporter but has not achieved innovations or, alternatively, one kind of innovation but is not an exporter. ABILITIES=o takes place when the firm is neither an exporter nor has achieved any kind of innovation. The ability to innovate is stated by firms responses "yes" or "no" to the questions: "Have you made a product (process) innovation during the last three years?" in the Unicredit questionnaire. The total number of firms is split into suppliers (selling to order to other firms) and final firms (selling only to the market). Firms selling to both are omitted. 
In accordance with other recent surveys (Altomonte and Aquilante, 20I2), the data presented in Table I show that in Italy the relative weight of supplier firms is high. Indeed, the last two columns of Panel B show that, on average, suppliers account for about $70 \%$ of the total number of industrial producers, with only relatively small differences among industries 9 and over time. The share of suppliers is about 4 percentage points above the average in "specialized sectors" ${ }^{\circ}$, but very close to the mean value in "science based industries" and "traditional industries" (particularly in 2006). As expected, these differences are somewhat larger across different size groups, with the share of suppliers being higher among SMEs than among large firms. Suppliers account for $7 \mathrm{I}-72 \%$ of the firms in the smallest size class (II-49 employees) but for still well over 50\% of those with over 250 employees.

The first four pairs of columns of Panel A of Table I report the distribution of all firms across the four different values of abilities, overall and by industry group and size class. The four ABILITIES categories (o-3) represent different levels of capability, as explained in the note to the Table. The figures in the first column for each of the four ABILITIES classes represent the averages over the entire 1998-2006 period, while those in the second column represent the corresponding averages for 2004-2006. The entries in Panel B of Table I represent the percentages of supplier firms in each such category.

From Panel A it can be seen that a relatively large share (almost $75 \%$ ) of producers export and/or innovate (the sum of the percentages of firms in ABILITIES categories I-3) and about $45 \%$ both export and innovate and/or make both product and process innovations (the sum of the ABILITIES categories 2 and 3). These percentages vary considerably, however, over industries and firm size. Firms in traditional and scale-intensive industries have somewhat higher shares of firms in ABILITIES $=0$, while firms in

9 For conciseness of presentation, in Table I we classify industries into the four groups of the Pavitt taxonomy, i.e., traditional, scale intensive, specialized, and sciencebased. In the econometric investigation of Sections 3.3 and 3.4 , we make use of a more detailed industry classification.

Not surprisingly, an especially high share of suppliers occurs in industries typically characterized by producer-driven chains, i.e., machinery and mechanical apparatus, electric appliances and electronics. 
specialized and science based sectors have larger shares in ABILITIES=3. The distribution of firms across these ability classes varies more sharply by size of firm group; around I/3 of the smallest firms are neither exporters nor innovators (ABILITIES $=0$ ), whereas among large firms (more than 250 employees) that share was less than 10\% in 2004-2006. Conversely, the share of large firms in the highest ability category ABILITIES $=3$ was almost $42 \%$ in $2004-2006$ and averaged over $37 \%$ over the $1998-2006$ period. Trends over time are noticeable from comparisons between the entries for the whole 1998-2006 period and that for 2004-2006 only. For each size class and industry group, the entries for highest ability (ABILITIES=3) group are larger for 2004-2006 than for the 1998-2006 average. While the increases in the shares of firms in the ABILITIES $=3$ category are larger for firms with 50 or more employees than for those in the II-49 size class, even for these latter there was an upward trend.

Finally, Panel B shows that the percentage of suppliers in all firms is some $6 \%$ higher among non-exporters and non-innovators (ABILITIES=0) than in the groups of higher ability producers (ABILITIES categories 2 or 3). Note also that this difference is greater among firms in traditional, specialized and science based industries. With regard to size, the data show that suppliers are relatively more numerous (constituting about $75 \%$ of the total) among non-exporting and non-innovating SMEs (up to 250 employees), while in the group of firms with over 250 employees that same share is below $60 \%$. While this evidence seems to point out a relative disadvantage of suppliers in terms of abilities, especially with respect to the ability to export and innovate, note that of the smallest firms (II-49 employees) with ABILITIES $=3$ more than $2 / 3$ of all firms are supplier firms.

\subsection{Firms' capabilities, participation in GVCs and firms' productivity}

\subsubsection{Estimating TFP}

To measure TFP at the level of the single firm, the literature proposes a variety of methodologies (index numbers, data envelopment analysis, parametric and semi-parametric methods), based on various assumptions 
and various estimation strategies, each inevitably showing both strong and weak points ${ }^{\mathrm{II}}$. In this investigation we choose to adopt a parametric approach that assumes a Cobb-Douglas production function for the individual firm with four factors of production. In the linearized version with logarithmic transformation, our function of production is:

$$
q_{i t}=\alpha+\beta_{k} k_{i t}+\beta_{l} l_{i t}+\beta_{r} r_{i t}+\beta_{s} s_{i t}+v_{i t}+e_{i t}
$$

where $q_{i t}$ represents the natural logarithm of output, $k, l, r$ and $s$ respectively the physical capital inputs, labour, raw materials and services (in $\operatorname{logs})^{12}$ and the error term consists of a factor determining productivity, specific for each firm $\left(v_{i t}\right)$, known to the firm itself and unknown to the econometrician, plus an idiosyncratic part unknown to either $\left(e_{i t}\right)$. We estimate the coefficients of (I) separately for each of nine industrial macrosectors, obtained by aggregation of the 2-digit ATECO I99I classification industries ${ }^{13}$. A measure of TFP is then obtained as follows:

II For a review, see for example Van Biesebroeck (2003) and Van Beveren (2007).

I2 Given the lack of data on the prices charged by the individual firms, the model variables - which originally represented the total revenues (dependent variable) and the costs of the capital input, raw materials and services (explanatory variables) in Euro - have been deflated making use of (annual) deflators of the industrial sector the firms belong to (base year I995; source: EU Klems, 2008). The labour variable, i.e. the number of employees, is obviously not affected by this adjustment. We also attempted to include human capital among the regressors by exploiting the data on the educational level of the employees, distinguishing between graduates, those with school leaving certificate, and those who left school at the earliest school-leaving age. However, since this information is available only for the last years of the three surveys (i.e. 2000, 2003 and 2006), and many firms omitted the answer, the number of observations proves to be too small to be used.

I3 The macro-sectors are: I) food products and beverages + tobacco and tobacco manufactures; 2) textile and clothing + leather and leather manufactures; 3) paper pulp, paper and articles of paper and paperboard + printing and publishing; 4) coal and coke, petroleum and petroleum products, treatment of nuclear fuel + chemicals, chemical products and synthetic and artificial fibres + rubber and plastics products; 5) non-metallic mineral manufactures + metalworking + manufactures of metals, excluding machinery and equipment; 6) machinery and mechanical apparatus; 7) office and computing machinery + electrical machinery + TV and communication equipment + precision, medical and optical instruments; 8) motor vehicles, engines and trailers + other transport equipment; 9) wood and products of wood and cork, excluding furniture + furniture and parts thereof + recycling + other manufactures. 


$$
T F P_{i t}=q_{i t}-\left(\hat{\beta}_{k} k_{i t}+\bar{\beta}_{l} l_{i t}+\bar{\beta}_{r} r_{i t}+\bar{\beta}_{s} s_{i t}\right)
$$

In estimating the parameters of the production function (I), the problems of endogeneity and non-random selection have to be reckoned with. Regarding the problem of endogeneity (or simultaneity), it is likely that each firm may be aware of factors $\left(v_{i t}\right)$ contributing to determining its productionbut unknown to the econometrician, as suggested by the specification of the error term in equation (I). In the profit maximising process, this information affects the firm's choice regarding the quantity of other inputs present in the production function. As a consequence, the hypothesis of exogeneity of regressors is no longer valid, thus distorting the results obtained with the adoption of a simple OLS estimator.

The problem of non-random selection (or attrition) arises when using balanced data panels, as attention is limited to firms that have always been active in the considered time span, whereas those that have started or terminated activity in the same period are excluded. By so doing, it is disregarded that, as Van Beveren (2007) sums it up, "several theoretical models (e.g. Jovanovic 1982; Hopenhayn 1992) predict that the growth and exit of firms is motivated to a large extent by productivity differences at the firm level".

In our case, the problem of non-random selection is to some extent reduced by the use of an unbalanced panel. Moreover, to tackle the problem of simultaneity illustrated above, use is made of the estimator proposed by Blundell and Bond (1998), applied by the authors themselves to estimate production functions (Blundell and Bond, 2000) ${ }^{\mathrm{I}}$. This estimator, also known as the System-GMM (SYS-GMM), is based on a GMM procedure which makes use, on the one hand, of lagged explanatory variables as instruments for the model in first differences (under the assumption of white noise errors, like the GMM-difference of Arellano and Bond,

I4 Olley and Pakes (1996) and Levinsohn and Petrin (2003) propose a semi-parametric approach to solve the problem of simultaneity. Olley and Pakes (1996), moreover, introduce an explicit correction for the selection problem, considering the likelihood of survival for each firm. Some extensions of their model have recently been introduced (for example, De Loecker, 2007). 
I99I), and, on the other hand, of lagged first differences (of the regressors) as instruments for the model in levels. These additional conditions of orthogonality "remain informative even for persistent series, and (the system estimator) has been shown to perform well in simulations" (Bond et al., 200I, p. 4), enhancing efficiency in estimation.

\subsubsection{Comparing suppliers' and final firms' TFP}

Once obtained the TFP estimates with application of the procedure described above, they are used to carry out a series of comparisons between groupings of firms singled out consistently with the purposes of our work ${ }^{15}$. More precisely, for each industry or group of industries, we carry out the following comparisons: I) within the subset of low-capabilities firms, we compare average TFP of final firms versus suppliers; 2) within the subset of high-capabilities firms, we compare average TFP of final firms versus suppliers; 3) within the suppliers' subset, we compare average TFP of highcapabilities and low-capabilities firms; 4) within the final firms' subset, we compare average TFP of high-capabilities and low-capabilities firms. The notion of high- or low-capabilities is connected to the value of the index ABILITIES defined above. More precisely, the high-capabilities subsample is constituted by firms with ABILITIES=2 and ABILITIES=3; conversely, the low-capabilities subsample includes firms with ABILITIES $=0$. The statistical significance of the differences between the average values of TFP is then tested. We repeat three times this procedure by alternatively using the standard one-step SYS-GMM estimation, the Windmeijer (2005) twostep procedure for finite samples and a reduced sample with small and medium-sized firms (not more than 250 employees) only. The results are summarized in Table 2.

\subsubsection{Comparing suppliers' and final firms' labour productivity}

The procedure followed in Section 3.2.2 is then replicated to compare suppliers' and final firms' labour productivity. In this case, the calculation of individual productivity is straightforward. Afterward, comparisons of the average labour productivity of different groups are made. Exactly like

I5 A similar approach is adopted for example by Gebreeyesus (2008). 
in the previous section, suppliers and final firms are firstly compared to each other with distinct comparisons for the two groups of high capabilities (ABILITIES $=2$ and ABILITIES $=3$ ) and low capabilities (ABILITIES=0) firms and nine different industries (or sets of industries). Secondly, considering separately suppliers and final firms, and the usual nine different industries (or sets of industries), the average labour productivity of exporters and innovators (firms with ABILITIES $=2$ and $\mathrm{ABILITIES}=3$ ) is compared to that of non-exporters and non-innovators (ABILITIES $=0$ ) and statistical significance of differences is tested. The results are reported in Table 3 .

\subsection{Results}

The coefficients shown in Table 2 are the differences in average TFP between two subsets of firms for 9 different sectors or groups of sectors.

In particular, in columns I, 5 and 9 the subsample of non-exporting and non-innovating firms is considered and firms are split into the groups of final firms (group I) and suppliers (group 2). Coefficients yield therefore an estimated measure of the difference between the TFP of final firms and suppliers. In 25 cases out of 27 , TFP of final firms comes out to be higher than TFP of suppliers (coefficients have positive signs); positive differences are statistically significant 2I times at a level of significance less than $5 \%$, and 24 times at a level of significance less than 10\%. Negative differences ( 2 cases out of 27 ) are never significant. 


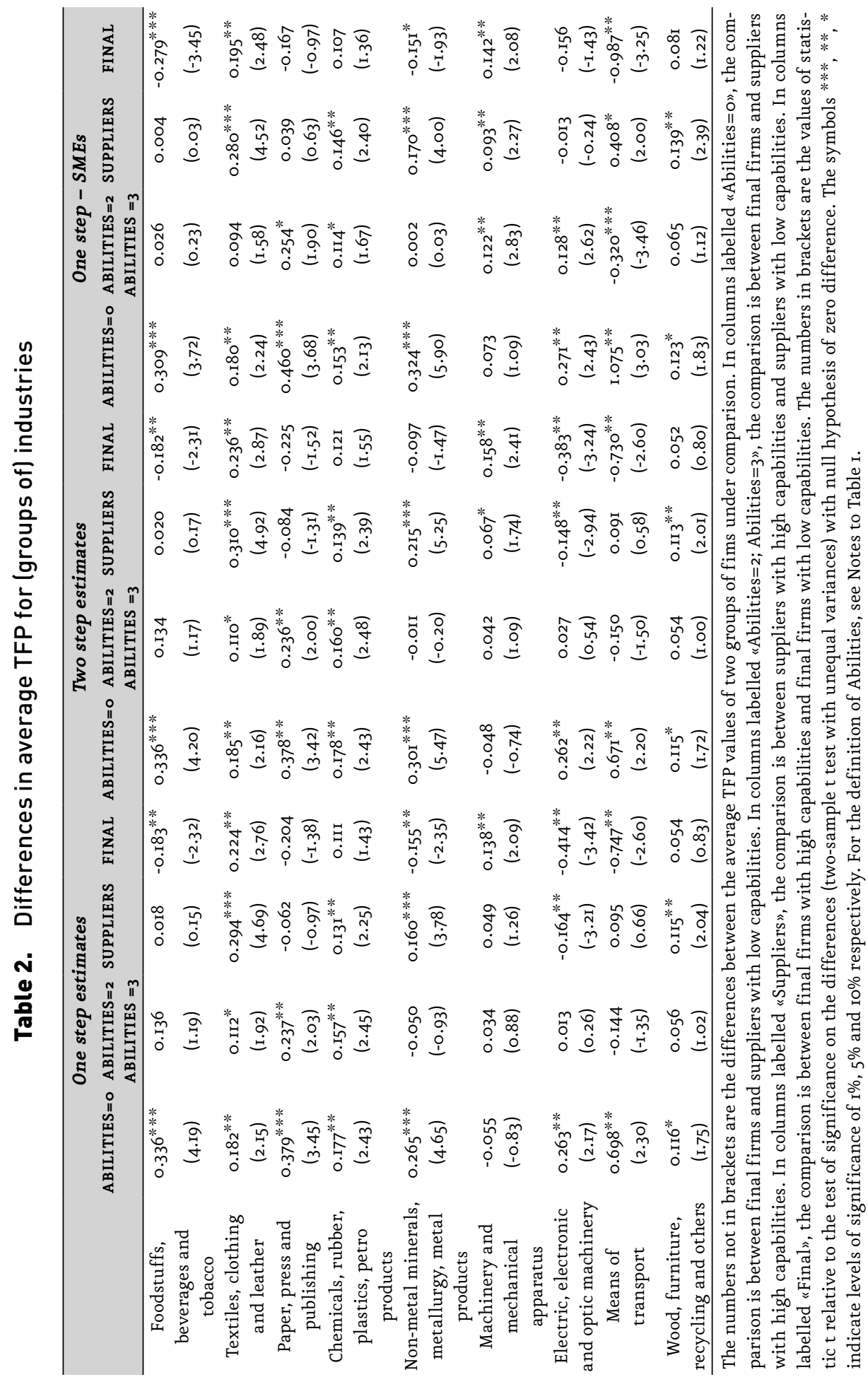


This outcome looks like an overwhelming evidence of a TFP advantage for final firms with respect to suppliers in the subset of non-exporting and non-innovating firms. Notably, the size of the gap is not uniform across industries and firms' size. The industries showing the most remarkable differences are the ones of: "paper", "metal working", "food" and especially "motor vehicles and transport equipment". Also, in "paper" and "metalworking" industries a more significant disadvantage for small and medium sized suppliers versus final firms of similar size is recorded. Summarizing, when considering suppliers without skills in exporting and innovating, (i.e. suppliers probably joining local value chains or GVCs with less advanced governance and low-quality relationships among its members), data confirm the traditional productivity gap of suppliers with respect to final firms with the same level of capabilities.

The figures in columns 2, 6 and Io of Table 2 represent the estimated TFP differences between final firms and suppliers when only the subset of exporting and innovating firms is considered. With respect to the previous comparisons, results are now clearly different. First of all, in 24 cases out of 27 the value of coefficients diminishes, while in 2 of the remaining cases coefficients are insignificant. The reduction amounts to more than $50 \%$ in I4 cases and more than $35 \%$ in 2I cases. Although the coefficients are still positive in most cases (22 out of 27 ), statistical significance at $5 \%$ or less is detected only in 6 cases (in Io cases at Io\% or less of significance); conversely, a negative significant gap (i.e. suppliers' TFP turns out to be significantly higher than final firms' TFP) emerges for SMEs in the industry of "motor vehicles and transport equipment", the sector for which the sharpest dissimilarity occurs when moving from the low-capabilities to the high-capabilities subsample. While, for the entire sample of high capabilities' firms, final firms remain more productive than suppliers in two sectors ("paper" and "petroleum, chemicals and plastics"), when considering the high capabilities' SMEs only, a modest but statistically significant (at $5 \%$ level) gap in favour of final firms is recorded just for mechanical and electronic sectors.

Clearly, the picture derived for the subset of exporting and innovating firms results to be dramatically changed in comparison with the conclusions drawn above for the low-capabilities firms. The most capable suppliers, i.e. the ones who are more likely to take part in relational GVCs and thus are required to have export abilities (as buyers are "global" and 
so often located abroad) and adequate propensity to innovate (because of more advanced modes of governance), in most cases perform as well as final firms and do not suffer any longer from TFP gaps.

This result is to some extent corroborated by the subsequent comparisons. In columns 3, 4, 7, 8, II and I2 of Table 2, the subsamples of suppliers and final firms only are alternatively considered to test the impact of higher capabilities on each subsample of firms. Again, within each subsample, firms are split into two groups (exporting and innovating versus non-exporting and non-innovating) and the difference in average TFP is calculated and statistically tested against the null hypothesis of zero difference. The expected result of a positive impact of greater skills on TFP is verified in 2I cases out of 54 (statistical significance at least at Io\% level). In I5 cases the improvement in TFP concerns suppliers, while only in 6 cases regards final firms. In addition, in the subsample of final firms, in Io cases the group with greater capabilities surprisingly shows significantly lower (rather than higher) TFP, while in the subsample of suppliers the same outcome takes place only twice (never when only small and medium sized suppliers are considered).

The latter evidence seems to indicate that export and innovation capabilities are for suppliers more important (than for final firms) to get higher levels of TFP. This finding, together with the previous one, describes a picture where skill and capability upgrading are especially crucial for suppliers aiming at increasing their productivity and filling the TFP gap with respect to final firms. In this vein, belonging to an advanced relational GVC may be vital for suppliers as the incentives and opportunities given by the global chain can stimulate and support the upgrading effort of the firm. This result, even if not invariant to the specificities connected to industry and size, appears quite neatly and seems to be sufficiently robust, even when changing the dependent variable, i.e. turning from TFP to labour productivity ${ }^{\mathrm{I}}$.

Table 3 replicates the results displayed in Table 2 with reference to the dependent variable LAPR (labour productivity).

I6 A similar result is obtained by Accetturo et al. (20II), who show that firms' strategies based on enhancement of innovation and export abilities are more beneficial for suppliers while strategies hinging on deepening human capital are more profitable for final firms. 


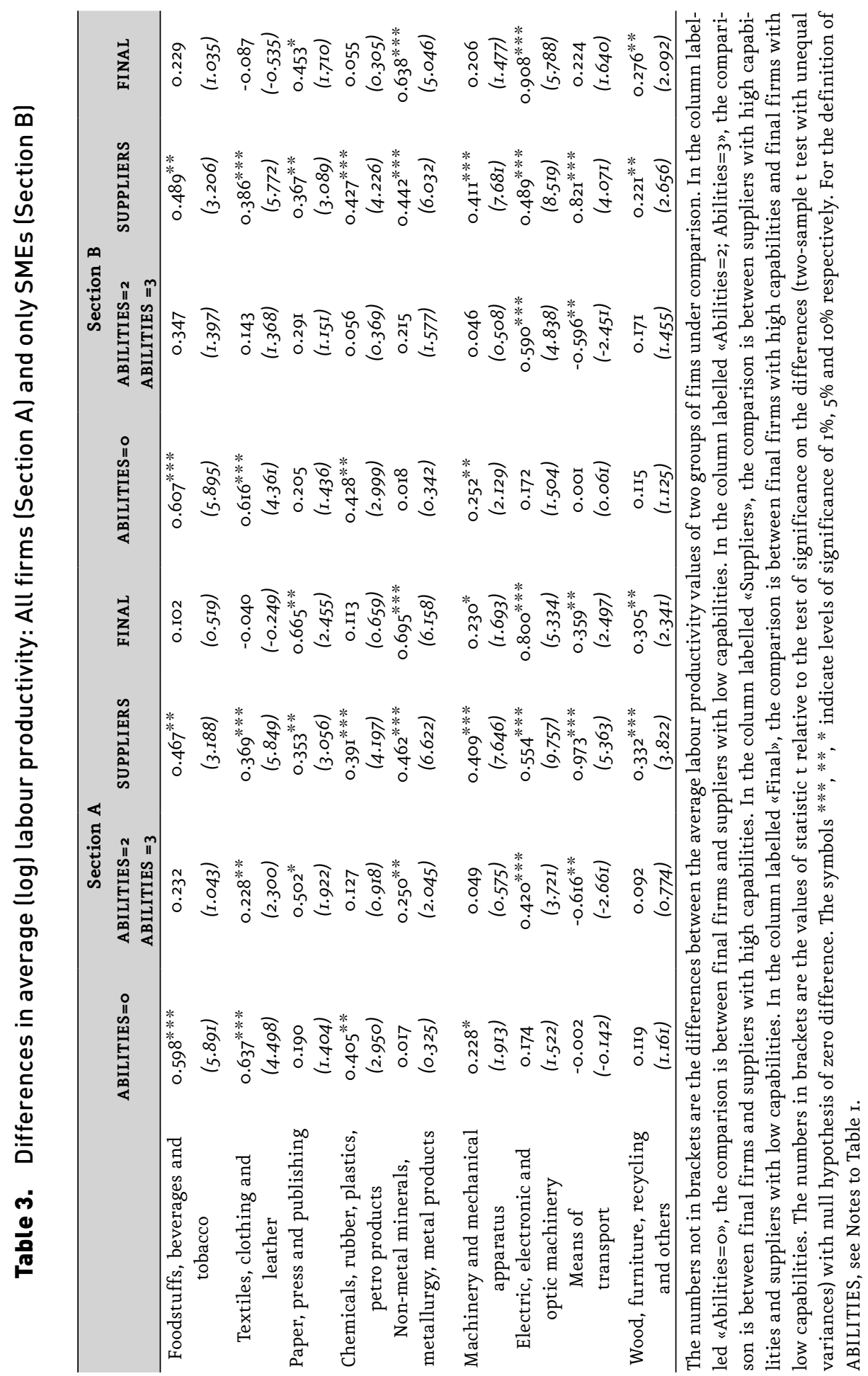


Again, for each sector or macro-sector, productivity differences between two groups of firms (final firms versus suppliers in columns I, 2, 5 and 6; high capabilities versus low capabilities firms in columns 3, 4, 7 and 8) are reported for different subsamples (only low capabilities, i.e. with ABILITIES $=0$, in columns I and 5; only high capabilities, i.e. with ABILITIES $=2$ or 3 , in columns 2 and 6 ; only suppliers in columns 3 and 7 ; only final firms in columns 4 and 8). The figures refer to differences of natural logarithms of original variables in order to make them comparable with results of Table 2. Data concern either the whole sample (columns I, 2, 3 and 4) or SMEs only (columns 5, 6, 7 and 8).

Like in the case of TFP, when moving from low capabilities to high capabilities firms (i.e. when comparing coefficients of columns i and 5 respectively with columns 2 and 6 ), we find that observed average differences between final firms and suppliers clearly shrink (although less strongly than in Table 2) in at least $2 / 3$ of cases. The only relevant exception is that of the "computing and communication machinery" industry, for which productivity differences between final firms and suppliers appear to be more important in the subsample of exporters and innovators ${ }^{17}$ than for others. The reduction in the value of coefficients amounts to more than $50 \%$ in 9 cases out of 18 , and more than $30 \%$ in II cases. Although in columns 2 and 6 (high capabilities' subsample) the coefficients representing productivity differences between final firms and suppliers are still positive in most cases (I6 out of $\mathrm{I} 8$ ), statistical significance at $5 \%$ or less is detected only in 4 cases (in 5 cases at Io\% or less of significance); conversely, a negative significant gap (i.e. suppliers' LAPR comes out to be significantly higher than final firms' LAPR) emerges for SMEs in the industry of "motor vehicles and transport equipment", exactly like for TFP in Table 2. While, for the entire sample of high capabilities' firms, final firms remain more productive than suppliers in the sectors of "textile and leather", "metal working" and "computing and communication machinery", just this latter industry keeps on showing a statistically significant gap in favour of final firms when only (high-capabilities) SMEs are considered.

I7 This happens also for "metalworking" and "paper and printing" sectors but in these cases the productivity differences are significant (barely significant for "paper and printing") only for large firms (compare coefficients in columns 2 and 6). 
The remaining columns of Table 3 are devoted to comparisons between high-capabilities and low-capabilities firms within the subsets of suppliers and final firms, for both the whole sample and the SMEs subsample. Here the evidence is even clearer than in Table 2: being capable yields a much greater return in terms of labour productivity for suppliers than for final firms (compare coefficients of columns 3 and 7 respectively with columns 4 and 8). The average gain in productivity connected to upgrading from "non-exporter and non-innovator" to "exporter and innovator" status is around $6 \mathrm{I} \%$ for suppliers (57\% for supplier SMEs) and $43 \%$ for final firms $\left(38 \%\right.$ for final SMEs) ${ }^{18}$. Moreover, the increase in LAPR is always strongly statistically significant ${ }^{19}$ for suppliers, while for final firms upgrading has a statistically significant ( $5 \%$ level) impact on labour productivity only in 8 cases out of $\mathrm{I} 8$, while in 2 cases ("textile and leather") the observed effect of upgrading is even negative.

\section{CONCLUDING REMARKS}

This paper partially fills a gap in the literature which has so far devoted relatively little attention to suppliers (firms selling to other firms, usually to order), even if these have long constituted the backbone of industrial systems, in both developed and emerging countries, and more recently the basis of the development of worldwide value chains. Unlike the traditional belief for which suppliers are relatively less productive than final firms, our results show a strong heterogeneity in suppliers' TFP and Labour Productivity, which prove to be both highly variable within the suppliers' set and closely connected to individual capabilities and participation in advanced-governance GVCs. More precisely, the evidence points out that suppliers with low export and innovation skills, usually joining captive GVCs, show a pretty large productivity gap vis-à-vis final firms, wider for TFP and SMEs. Conversely, suppliers with high capabilities, probably joining advanced-governance relational GVCs, show TFP and LAPR levels on average not lower than final firms. Finally, the effect of export

I8 These values are calculated as $\exp \left(\bar{d}_{L A P R}\right)$, where $\bar{d}_{L A P R}$ is the simple average across industries of coefficients in columns $3,4,7$ and 8.

I9 The $t$ statistic exceeds the value 3 in 17 cases out of 18 , and is about 2.7 in the remaining case. 
and innovation abilities comes out to be more relevant for suppliers than others, highlighting how important is upgrading for suppliers involved in GVCs.

Thus we conclude that GVCs and particularly relational GVCs do matter in determining suppliers' performance, because the participation in global chains imposes constraints and offers incentives, so forcing suppliers to develop their capabilities, gain efficiency and close the productivity gap with final firms.

\section{REFERENCES}

ACCETTURO, A., GIUNTA, A. and ROSSI, S. (20II), "Le imprese italiane tra crisi e nuova globalizzazione", L'Industria, $\mathrm{n}^{\circ} \mathrm{I}$, pp. I45-164.

ACCETTURO, A., GIUNTA, A. and ROSSI, S. (20I2), "Being in a Global Value Chain: Hell or Heaven?". Website: http://www.voxeu.org/article/being-global-value-chainhell-or-heaven, December I5.

AGOSTINO, M., GIUNTA, A., NUGENT, J. B., SCALERA, D., and TRIVIERI, F. (20II), “Firm productivity, organizational choice and global value chain", Orkestra Working Paper Series in Territorial Competitiveness, $\mathrm{n}^{\circ}$ Rog.

ALtOMONTE, C., AQUILANTE, T. (2012), The EU-EFIGE/Bruegel-Unicredit dataset, Bruegel University, Bruxelles.

AMIGHINI, A. and RABELLOTTI, R. (2003), "The effect of globalisation on industrial districts in Italy: evidence from the footwear sector", SEMEQ Department Working Paper, No. 64, Università del Piemonte Orientale.

ANTRAS, P. (2003), "Firms, contracts, and trade structure", Quarterly Journal of Economics, vol. II8, pp. I375-I4I8.

ANTRAS, P. (2005), "Incomplete contracts and the product cycle", American Economic Review, vol. 95, pp. I054-1073.

ANTRAS, P. and HELPMAN, E. (2004), "Global sourcing", Journal of Political Economy, vol. II2, pp. 552-580.

ANTRAS, P. and HELPMAN, E. (2008), Contractual frictions and global sourcing, in E. Helpman, D. Marin and T. Verdier (eds.) The Organization of Firms in a Global Economy, Harvard University Press.

AOKI, M. (1988), Information, Incentives and Bargaining Structures in the Japanese Economy, Cambridge University Press.

ARNDT, S. and KIERZKOWSKI, H. (200I), Fragmentation: New Production Patterns in the World Economy, Oxford University Press.

ARELlANO, M. and BOND, S. (I99I), "Some tests of specification for panel data: Monte Carlo evidence and an application to employment equations", Review of Economic Studies, 58, 277-297.

BALDWIN, R. and ROBERT-NICOUD, F. (20Io), “Trade-in-goods and trade-in-tasks: An integrating framework", CEPR Discussion Paper, No. 7775, April. 
BAIR, J. and GEREFFI, G. (200I), "Local clusters in global chains: the causes and consequences of export dynamism in Torreon's blue jeans industry", World Development, vol. 29, pp. I885-1903.

BARBA NAVARETTI, G., BUGAMELLI, M., SCHIVARDI, F., ALTOMONTE, C., HORGOS, D. and MAGGIONI, D. (20II), "The global operations of European firms. The second EFIGE policy report", Bruegel Blueprint Series, vol. I2.

BARRIENTOS, S., GEREFFI, G. and ROSSI, A. (2OII), "Economic and social upgrading in global production networks: A new paradigm for a changing world", International Labor Review, vol. I50, pp. 319-340.

BAZAN, L. and NAVAS-ALEMAN, L. (2004), The underground revolution in the Sinos Valley: a comparison of upgrading in global and national value-chains, in H. Schmitz (ed.), Local Enterprises in the Global Economy: Issues of Governance and Upgrading. Edward Elgar, Cheltenham.

BEAUDREAU, B. C. (20II), "Vertical comparative advantage", International Trade Journal, vol. 23, pp. 305-348.

BLUNDELL, R. and BOND, S. (1998), "Initial conditions and moment restrictions in dynamic panel data models", Journal of Econometrics, vol. 87, pp. II5-I43.

BOND, S., TEMPLE, J. and HOEFFLER, A. (200I), “GMM Estimation of Empirical Growth Models", Economics Papers, 2I, Nuffield College, University of Oxford.

BLUNDELL, R. and BOND, S. (2000), "GMM estimation with persistent panel data: an application to production functions", Econometric Reviews, vol. I9, pp. 32I-340.

CAMUFFO, A., FURLAN, A. and GRANDINETTI, R. (2007), Knowledge and capabilities in subcontractor's evolution: the Italian case, in G. I. Susman (ed.), Small and MediumSized Enterprises and the Global Economy, Edward Elgar, Cheltenham, pp. 125-I39.

CATTANE0, 0., GEREFFI, G. and STARITZ, C. (20I0), Global Value Chains in a Postcrisis World. A Development Perspective, The World Bank, Washington.

CATTANEO, O., GEREFFI, G., MIROUDOT, S. and TAGLIONI, D. (2013), “Joining, upgrading and being competitive in global value chains. A strategic framework", World Bank Policy Research Working Paper, No. 6406.

COMITATO NETWORK SUBFORNITURA (2008), “Osservatorio Subfornitura. Rapporto annuale. Sistema moda", Bologna.

DE LOECKER, J. (2007), "Product differentiation, multi-product firms and estimating the impact of trade liberalization on productivity", NBER Working Paper Series, No. I3155.

DOLAN, C. AND HUMPHREY, J. (2000), “Changing governance patterns in the trade in fresh vegetables between Africa and the United Kingdom", Environment and Planning A, vol. 36, pp. 49I-509.

DRIES, L. and SWINNEN, J. F. M. (2004), "Foreign direct investment, vertical integration, and local suppliers: Evidence from the Polish dairy sector", World Development, vol. 32, pp. 1525-44.

EU KLEMS (2008), Growth and Productivity Accounts. Productivity in the European Union: A Comparative Industry Approach. Website: www.euklems.net/project_site.html.

FEENSTRA, R. (1998), "Integration of trade and disintegration of production in the global economy", Journal of Economic Perspectives, vol. I2, pp. 3I-50. 
FRANTZEN, D. (2000), "Innovation, international technological diffusion and the changing influence of RED on productivity", Cambridge Journal of Economics, vol. 24, pp. 193-210.

FRÖBEL, F., HEINRICHS, J. and KREYE, O. (I98I), The New International Division of Labour: Structural Unemployment in Industrialised Countries and Industrialisation in Developing Countries, Cambridge University Press.

GALVIN, P. and MORKEL, A. (200I), "The effect of product modularity on industry structure: The case of the world bicycle industry", Industry and Innovation, vol. 8, pp. 3I-47.

GEBREEYESUS, M. (2008), "Firm turnover and productivity differentials in Ethiopian manufacturing", Journal of Productivity Analysis, vol. 29, pp. II3-I29.

GEREFFI, G. (I994), The organization of buyer-driven commodity chains: How US retailers shape overseas production networks, in G. Gereffi and M. Korzeniewicz (eds.), Commodity Chains and Global Capitalism, Greenwood Press, Westport, pp. 95-I22.

GEREFFI, G. (1999), "International trade and industrial upgrading in the apparel commodity chain", Journal of International Economics, vol. 48, pp. 37-70.

GEREFFI, G. and FREDERICK, S. (20I0), The global apparel value chain, trade, and the crisis: Challenges and opportunities for developing countries, in 0. Cattaneo, G. Gereffi, and C. Staritz (eds.), Global Value Chains in a Postcrisis World. A Development Perspective, The World Bank, Washington.

GEREFFI, G., HUMPHREY, J. and STURGEON, T. (2005), “The governance of global value chains", Review of International Political Economy, vol. I2, pp. 78-II4.

GiUliani, E., PIETROBelli, C. and RABEllotTI, R. (2005), "Upgrading in global value chains: Lessons from Latin American clusters", World Development, vol. 33, pp. 549-573.

GIUNTA, A., NIFO, A. and SCALERA, D. (2012), "Subcontracting in Italian industry: Labour division, firm growth and the North-South divide", Regional Studies, vol. 46, pp. 1067-Io83.

GIUNTA, A. and SCALERA, D. (2007), “L'impresa subfornitrice: redditività, produttività e divari territoriali", Economia e Politica Industriale, vol. 34, pp. 123-I46.

GREENAWAY, D. and KNELLER, R., (2007), "Firm heterogeneity, exporting and foreign direct investment", Economic Journal, vol. II7, pp. Fi34-Fi6r.

GROSSMAN, G. and ROSSI-HANSBERG, E. (2006), "The rise of offshoring: It's not wine for cloth anymore", paper presented at Kansas Fed's Jackson Hole Conference for Central Bankers.

HANSON, G. H., MATALONI, R. J. and SLAUGHTER, M. J. (2005), "Vertical production networks in multinational firms", Review of Economics and Statistics, vol. 87, pp. 664-678.

HAVIK, K. and MCMORROW, K. (2006), "Global trade integration and outsourcing: how well is the EU coping with the new challenges?", European Commission DirectorateGeneral for Economic and Financial Affairs Economic Papers, No. 259.

HELPMAN, H., MELITZ, M. J. and YEAPLE, S. R. (2004), “Export versus FDI with heterogeneous firms", American Economic Review, vol. 94, pp. 300-316.

HENDERSON, J., DICKEN, P., HESS, M., COE, N. and YEUNG, H. (2002), “Global production networks and the analysis of economic development", Review of International Political Economy, vol. 9, pp. 436-64. 
HOPENHAYN, H. A. (1992), "Entry, exit and firm dynamics in long run equilibrium", Econometrica, vol. 6o, pp. II27-II50.

HUMMELS, D., ISHII, J. and YI, K. M. (200I), "The nature and growth of vertical specialization in world trade", Journal of International Economics, vol. 54, pp. 75-96.

HUMPHREY, J. (2003), "Globalization and supply chain networks: The auto industry in Brazil and India", Global Networks, vol. 3, pp. I2I-I4I.

HUMPHREY, J. and SCHMITZ, H. (2002), "How does insertion in global value chains affect upgrading in industrial clusters?", Regional Studies, vol. 36, pp. IOI7-IO27.

INNOCENTI, A. and LABORY, S. (2004), "Outsourcing and information management. A comparative analysis of France, Italy and Japan in both small and large firms", European Journal of Comparative Economics, vol. I, pp. I07-I25.

IVARSSON, I. and ALVSTAM, C. G. (20I0), "Supplier upgrading in the home-furnishing value chain: an empirical study of Ikea's sourcing in China and South East Asia", World Development, vol. II, pp. 1575-1587.

JOVANOVIC, B. (1982), "Selection and the evolution of industry", Econometrica, vol. 50, pp. $649-670$.

KAPLINSKI, R. (2000), "Spreading the gains from globalisation: What can be learned from Value Chain Analysis?", Institute for Development Studies Working Paper, No. IIo, Sussex University, Brighton.

KIMURA, F. (2002), "Subcontracting and the performance of small and medium firms in Japan", Small Business Economics, vol. 18, pp. 163-175.

LEVINSOHN, J. and PETRIN, A. (2003), "Estimating production functions using inputs to control for unobservables", Review of Economic Studies, vol. 70, pp. 317-34I.

MARIN, D. (2006), "A new international division of labor in Europe: Outsourcing and offshoring to Eastern Europe", Journal of the European Economic Association, vol. 4, pp. 612-622.

MELITZ, M. (2003), "The impact of trade on intra-industry reallocations and aggregate industry productivity", Econometrica, vol. 71, pp. 1695-1725.

MET - MONITORAGGIO ECONOMIA TERRITORIO (2009), Rapporto MET. Imprese e Politiche in Italia, Roma.

MIROUDOT, S. and RAGOUSSIS, A. (2009), "Vertical trade, trade costs and FDI", OECD Trade Policy, Working Paper, No. 89.

MORRISON, A., PIETROBELLI C. AND RABELLOTTI R. (2008), “Global value chains and technological capabilities: A framework to study learning and innovation in developing countries", Oxford Development Studies, vol. 36, pp. 39-58.

OECD (2007), Offshoring and Employment. Trends and Impacts, Paris.

OLLEY, S. AND PAKES, A. (1996), "The dynamics of productivity in the telecommunications equipment industry", Econometrica, vol. 64, pp. 1263-1295.

PLANCK, L. and STARITZ, C., (2013) “'Precarious upgrading' in electronics global production networks in Central and Eastern Europe: the cases of Hungary and Romania", Capturing the Gains Working Paper, No. 31. Website: http://ssrn.com/ abstract $=225967 \mathrm{I}$.

PONTE, S. and EWERT, J. (2009), "Which way is 'up' in upgrading? Trajectories of change in the value chain for South African wine", World Development, vol. 37, pp. I637-1650. 
PIETROBELli, C. and RABELlOtTI, R. (2007), Upgrading to Compete: Global Value Chains, Clusters and SMEs in Latin America, Harvard University Press.

RAZZOLINI, T. and VANNONI, D. (20II), "Export premia and subcontracting discount: Passive strategies and performance in domestic and foreign markets", World Economy, vol. 34, pp. 984-Ior3.

SALLEZ, A. (1977), " De l'analyse structurelle de la firme à la division spatiale du travail ", Économie appliquée, $\mathrm{n}^{\circ}$ 2, pp. 32-50.

STURGEON, T. J. (2002), "Modular production networks: a new American model of industrial organisation", Industrial and Corporate Change, vol. II, pp. 45I-496.

STURGEON, T. J. and FLORIDA, R. (2004), Globalization, deverticalization, and employment in the motor vehicle industry, in M. Kenny and R. Florida (eds.), Locating Global Advantage: Industry Dynamics in a Globalizing Economy, Stanford University Press.

STURGEON, T. J. and LESTER, R. (2004), The new global supply-base: New challenges for local suppliers in East Asia, in S. Yusuf, M. A. Altaf, and K. Nabeshima (eds.), Global Production Networking and Technological Change in East Asia, Oxford University Press.

TAYMAZ, E. and KILIGASLAN, Y. (2005), "Determinants of subcontracting and regional development: an empirical study on Turkish textile and engineering industries", Regional Studies, vol. 39, pp. 633-645.

TOSCHI, G. (20I2), "Innovation, functional and competitive upgrading along the global value chain of enterprises located in Italian industrial districts", Economia e Politica Industriale - Journal of Industrial and Business Economics, vol. 39, pp. 7I-86.

UNICREDIT (2008), Rapporto Corporate Unicredit. X Indagine sulle Imprese Manifatturiere, Roma.

VAN BEVEREN, I. (2007), "Total factor productivity estimation: a practical review", Katholieke Universiteit Leuven Discussion Paper, No. I82.

VAN BIESEBROECK, J. (2003), "Revisiting some productivity debates", NBER Working Paper Series, No. 10065. Website: http://www.nber.org/papers/wioo65.

VAN WELSUM, D. (2004), “In search of 'off shoring': Evidence from U.S. imports of services", Birkbeck Working Paper in Economics and Finance, No. 402.

WINKLER, D. (2013), "Potential and actual FDI spillovers in global value chains", World Bank Policy Research Working Paper, No. 6424. 